\title{
Bioenergetics model for estimating food requirements of female Pacific walruses Odobenus rosmarus divergens
}

\author{
S. R. Noren ${ }^{1, *}$, M. S. Udevitz ${ }^{2}$, C. V. Jay ${ }^{2}$ \\ ${ }^{1}$ Institute of Marine Science, University of California, Santa Cruz, Santa Cruz, California 95060, USA \\ ${ }^{2}$ US Geological Survey, Alaska Science Center, Anchorage, Alaska 99508, USA
}

\begin{abstract}
Pacific walruses Odobenus rosmarus divergens use sea ice as a platform for resting, nursing, and accessing extensive benthic foraging grounds. The extent of summer sea ice in the Chukchi Sea has decreased substantially in recent decades, causing walruses to alter habitat use and activity patterns which could affect their energy requirements. We developed a bioenergetics model to estimate caloric demand of female walruses, accounting for maintenance, growth, activity (active in-water and hauled-out resting), molt, and reproductive costs. Estimates for nonreproductive females $0-12$ yr old $\left(65-810 \mathrm{~kg}\right.$ ) ranged from 16359 to $68960 \mathrm{kcal} \mathrm{d}^{-1}(74-257 \mathrm{kcal}$ $\mathrm{d}^{-1} \mathrm{~kg}^{-1}$ ) for years with readily available sea ice for which we assumed animals spent $83 \%$ of their time in water. This translated into the energy content of 3200-5960 clams per day, equivalent to $7-8 \%$ and $14-9 \%$ of body mass per day for $5-12$ and $2-4$ yr olds, respectively. Estimated consumption rates of $12 \mathrm{yr}$ old females were minimally affected by pregnancy, but lactation had a large impact, increasing consumption rates to $15 \%$ of body mass per day. Increasing the proportion of time in water to $93 \%$, as might happen if walruses were required to spend more time foraging during ice-free periods, increased daily caloric demand by $6-7 \%$ for non-lactating females . We provide the first bioenergetics-based estimates of energy requirements for walruses and a first step towards establishing bioenergetic linkages between demography and prey requirements that can ultimately be used in predicting this population's response to environmental change.
\end{abstract}

KEY WORDS: Pinniped $\cdot$ Foraging $\cdot$ Metabolism $\cdot$ Energetics $\cdot$ Arctic $\cdot$ Ice $\cdot$ Climate change

Resale or republication not permitted without written consent of the publisher

\section{INTRODUCTION}

Pacific walruses Odobenus rosmarus divergens are gregarious, pagophilic, highly specialized shallow benthic foragers (Fay 1982). Their range is primarily from the eastern East Siberian Sea to the western Beaufort Sea and southward into the Bering Sea from eastern Kamchatka to Bristol Bay (Fay 1985). They forage along the continental shelves of the Chukchi and Bering Seas (Fay \& Burns 1988, Jay et al. 2011), and although they feed on a wide variety of organisms, their diets are dominated by clams, snails, and polychaete worms (Fay 1982, Sheffield \& Grebmeier
2009). Sea ice is important, because it provides a platform for walruses to rest, nurse, and gain access to offshore foraging grounds (Fay 1982).

The extent of summer sea ice in the Chukchi Sea has decreased substantially in recent decades (Meier et al. 2007), and this trend is expected to continue (Overland \& Wang 2007, Douglas 2010). As sea ice retreats off the shallow continental shelf and over deep Arctic Ocean waters, it may become difficult for walruses to feed in proximity to sea ice. The lack of summer sea ice over the continental shelf in the Chukchi Sea over the past decade has resulted in increased use of terrestrial haul-outs by adult female 
and young walruses (Jay \& Fischbach 2008, Kavry et al. 2008). As summer sea ice extent continues to decline, it is expected that the number of walruses converging on coastal haul-outs and the time they spend ashore will increase (Jay et al. 2011). However, the ability of the localized food supply in these regions to support large numbers of walruses over the long term is unknown (Ovsyanikov et al. 2008). Changes in access to prey could impact body condition and ultimately impact population growth rates (Jay et al. 2011).

Deriving linkages between the responses of walruses to changing Arctic conditions requires an understanding of their energetics and food requirements. Direct measurements of field metabolic rate (Acquarone et al. 2006) and observations of foraging (Born et al. 2003) would provide the best quantifications of the energetic requirements and food consumption rates of wild walruses; however, these measurements are difficult to obtain because walruses are remotely distributed and forage along the sea floor. Several other approaches have been employed to estimate food consumption in marine mammals, including analyses of stomach contents and scat from wild animals and observations of feeding by captive animals. Unfortunately, each of these methodologies has inherent errors that could bias estimates of food consumption. For example, errors in food consumption estimates based on analyses of stomach contents (for review see Sheffield et al. 2001) or scat (for review see Arim \& Naya 2003) result from disparate digestion rates of remains and the corresponding underrepresentation of soft-bodied prey (Sheffield \& Grebmeier 2009). Meanwhile, differences between the activity budgets and environmental demands of captive versus wild animals and the potential for overfeeding (or underfeeding) captive animals limits the applicability of feeding rates from captive animals for estimates of feeding rates for wild populations.

Bioenergetic modeling is an alternate approach that has been used to estimate the energy consumption for a variety of marine mammals (i.e. Lavigne et al. 1982, Øristland \& Markussen 1990, Ryg \& Øristland 1991, Olesiuk 1993, Hammill et al. 1997, Stenson et al. 1997, Winship et al. 2002, Winship \& Trites 2003, Noren 2011), but has yet to be applied to walruses. Bioenergetics models range in detail from simple equations (with few parameters) representing an average individual's annual energy consumption, to detailed energy budgets (with many parameters) for each age- and sex-class and day of the year. A criticism of bioenergetics models is that they often use inaccurate approximations for parameter values. A complex model requires estimation of several parameters that could result in unanticipated interactions, and each additional parameter has an associated error that may substantially reduce the precision of the model (Stenson et al. 1997). One way to address this is to use fewer parameters estimated with increased precision (Winship et al. 2002), as has been done in several bioenergetics models for marine mammals (i.e. Mohn \& Bowen 1996, Stenson et al. 1997). We used this parsimonious approach to develop a bioenergetics model for the Pacific walrus. Our model estimates daily caloric demands of 0 to $12 \mathrm{yr}$ old female walruses based on the metabolic costs of activity (active in-water or hauled-out resting), growth, and molt, and the increased food consumption rates associated with reproduction (pregnancy and lactation). We used the model to (1) estimate annual energy requirements for female walruses as a function of age and reproductive state, (2) estimate changes in energy requirements due to changes in haul-out activity, and (3) determine which bioenergetic parameters have the largest influence on estimates of energy requirements.

\section{MATERIALS AND METHODS}

\section{Modeling approach}

Our model estimates daily caloric demands of 0 to $12 \mathrm{yr}$ old female Pacific walruses based on massspecific metabolic costs associated with their haulout activity budgets (Udevitz et al. 2009) and life history stages (Fay 1982, 1985). Because female walruses achieve full body size at age 12 (Fay 1982), the caloric demands for females $>12 \mathrm{yr}$ were assumed to be equivalent to those of $12 \mathrm{yr}$ olds. Activity was categorized as either hauled out (resting) or in water (active). Life history stages included molt, pregnancy, and lactation.

Metabolic costs for each activity and life history stage were expressed as a multiple of Kleiber, where Kleiber is the resting metabolic rate of an animal equivalent to $\mathrm{kcal} \mathrm{d}^{-1}=70 \times$ mass $^{0.75}$ (Kleiber 1975). The daily proportions for each of these costs were varied throughout the year to reflect changes in activity patterns and life history stages. Additional costs associated with early growth were included in the form of a multiplicative growth premium (Hammill et al. 1997) up to age 6 when female walruses achieve sexual maturity. The total daily metabolic cost was then corrected for digestive efficiency. Thus, 
the energetic requirement, $E(t)$, in kcal $\mathrm{d}^{-1}$ for a female walrus on day $t$ was given by

$$
\begin{gathered}
E(t)=\left\{\left[C_{\mathrm{w}} P_{\mathrm{w}}(t)+C_{\mathrm{h}} P_{\mathrm{h}}(t)\right] G(t)+C_{\mathrm{m}} P_{\mathrm{m}}(t)+C_{\mathrm{p}} P_{\mathrm{p}}(t)+C_{\mathrm{l}} P_{1}(t)\right\} \\
\cdot K_{1} M(t)^{\mathrm{K}_{2}} / D
\end{gathered}
$$

where $C_{\mathrm{w}}$ is the cost of being active in water, $C_{\mathrm{h}}$ is the cost of resting while hauled out (includes ice and terrestrial platforms), $C_{\mathrm{m}}$ is the cost of molting, $C_{\mathrm{p}}$ is the cost of pregnancy during the third trimester, and $C_{\mathrm{l}}$ is the cost of lactation, all in $\mathrm{kcal} \mathrm{d}^{-1} . P_{i}(t)$ is the proportion of day $t$ associated with cost $i$. $G(t)$ is the growth premium, a unitless multiplier. $M(t)$ is the mass on day $t$ in $\mathrm{kg} . K_{1}$ and $K_{2}$ are the Kleiber constants ( $K_{1}=$ $70, K_{2}=0.75$ ) and $D$ is the digestive efficiency (unitless). Parameter values are described in detail below.

\section{Parameter values}

All parameter values were derived from values reported in the literature. We used values specifically reported for walruses when they were available, but because of difficulties in studying this species, including logistics associated with their remote habitats and their well-developed startle response (stampeding and fleeing into the water), few physiological data were available. Thus, where data for walruses were lacking, data from other species of pinnipeds (particularly otariids) were used. Odobenid life history patterns and phylogeny are most similar to otariids. Like otariids, odobenids do not undergo extreme seasonal fasting periods related to breeding, lactating, and molting as do phocids, but rather these events occur over a longer time span and are combined with regular feeding (Fay 1982, Kovacs \& Lavigne 1992). Furthermore, recent genetics studies have demonstrated that odobenids are more closely related to otariids than to phocids (Schröder et al. 2009, Agnarsson et al. 2010, Fulton \& Strobeck 2010).

At the time of this investigation, the California sea lion Zalophus californianus was the only otariid for which the costs of life history stages (molt, pregnancy, and lactation) had been measured directly (Table 1). Activity costs were based on direct measurements of

Table 1. Metabolic and food consumption rate estimates used in our bioenergetics model for female Pacific walruses

\begin{tabular}{|c|c|c|c|c|}
\hline $\begin{array}{l}\text { Activity or } \\
\text { life history } \\
\text { stage }\end{array}$ & Specimen & Data (method) & $\begin{array}{l}\text { Conversion into units } \\
\text { of Kleiber } \\
\text { for model input }\end{array}$ & Source \\
\hline $\begin{array}{l}\text { Rest hauled-out } \\
\left(C_{\mathrm{h}}\right)\end{array}$ & $\begin{array}{l}3 \text { captive non-reproductive } \\
\text { female }(89.2 \pm 0.8 \mathrm{~kg}) \\
\text { and } 2 \text { wild pregnant } \\
(98.3 \pm 1.6 \mathrm{~kg}) \text { California } \\
\text { sea lions Zalophus } \\
\text { californianus }\end{array}$ & $\begin{array}{l}2.2 \times \text { Kleiber } \\
\text { (open-flow } \\
\text { respirometry) }\end{array}$ & $2.2 \times$ Kleiber & Williams et al. (2007) \\
\hline $\begin{array}{l}\text { Active in-water } \\
\left(C_{\mathrm{w}}\right)\end{array}$ & $\begin{array}{l}2 \text { wild male walruses } \\
\text { O. rosmarus } \\
(1250 \text { and } 1370 \mathrm{~kg})\end{array}$ & $\begin{array}{l}417.4 \text { and } 345 \mathrm{MJ} \mathrm{d}^{-1} \\
\text { (doubly labeled water) }\end{array}$ & $\begin{array}{l}79.81 \mathrm{kcal} \mathrm{d}^{-1} \mathrm{~kg}^{-1} \\
=6.8 \times \mathrm{Kleiber} \& \\
60.19 \mathrm{kcal} \mathrm{d}^{-1} \mathrm{~kg}^{-1} \\
=5.2 \times \text { Kleiber } \\
\text { Avg }=6 \times \text { Kleiber }\end{array}$ & $\begin{array}{l}\text { Acquarone et al. } \\
(2006)\end{array}$ \\
\hline $\begin{array}{l}\text { Molt } \\
\left(C_{\mathrm{m}}\right)\end{array}$ & $\begin{array}{l}3 \text { captive non- } \\
\text { reproductive female } \\
\text { California sea lions } \\
(89.2 \pm 0.8 \mathrm{~kg})\end{array}$ & $\begin{array}{l}1.3 \text { times greater than } \\
\text { resting metabolic rate } \\
\text { during post-molt } \\
\text { (open-flow respirometry) }\end{array}$ & $\begin{array}{l}\text { Caloric cost of molt } \\
\text { without basal costs }= \\
{[(1.3 \times 2.2)-2.2] \times \text { Kleiber }} \\
=0.66 \times \text { Kleiber }\end{array}$ & Williams et al. (2007) \\
\hline $\begin{array}{l}\text { Third trimester } \\
\text { of pregnancy } \\
\left(C_{p}\right)\end{array}$ & $\begin{array}{l}2 \text { wild pregnant } \\
\text { California sea lions } \\
(98.3 \pm 1.6 \mathrm{~kg})\end{array}$ & $\begin{array}{l}42 \% \text { higher than } \\
\text { resting metabolic rate } \\
\text { (caloric intake) }\end{array}$ & $\begin{array}{l}\text { Caloric cost of pregnancy } \\
\text { without basal costs }= \\
{[(1.42 \times 2.2)-2.2] \times \text { Kleiber }} \\
=0.924 \times \text { Kleiber }\end{array}$ & Williams et al. (2007) \\
\hline $\begin{array}{l}\text { Lactation } \\
\left(C_{1}\right)\end{array}$ & $\begin{array}{l}2 \text { wild lactating } \\
\text { female California } \\
\text { sea lions }(98.3 \pm 1.6 \mathrm{~kg})\end{array}$ & $\begin{array}{l}3.6 \text { times higher than } \\
\text { resting metabolic rate } \\
\text { (caloric intake) }\end{array}$ & $\begin{array}{l}\text { Caloric cost of lactation } \\
\text { without basal } \\
\text { costs }=[(3.6 \times 2.2)-2.2] \\
\times \text { Kleiber }=5.72 \times \text { Kleiber }\end{array}$ & Williams et al. (2007) \\
\hline
\end{tabular}
Odobenus rosmarus divergens 
metabolism for adults and therefore included basal costs, which are maintenance activities including thermoregulation. Costs associated with life history stages (molt, pregnancy, and lactation) excluded basal costs because maintenance costs were already incorporated into the activity parameters. The initial body mass for each age class was estimated as 65 , $195,270,345,420,495,570,645,725,755,785,810$, and $830 \mathrm{~kg}$ for 0 to $12 \mathrm{yr}$ old walruses, respectively, from Fay (1982: Fig. 21). The asymptotic mass of female Pacific walruses is $830 \mathrm{~kg}$, which is attained by 12 yr postpartum (Fay 1982). The growth premium multiplier was included in accordance with Hammill et al. (1997) and described in detail by Olesiuk (1993). The growth premium accounts for additional energy required for growth, which for neonatal pinnipeds is 1.8 times predicted adult maintenance requirements (Worthy 1987), and is assumed to converge on adult levels at the onset of sexual maturity at an exponential rate. This gave initial values of 1.8, 1.6, 1.4, 1.3, $1.1,1.1$, and 1.0 for $0,1,2,3,4,5$, and $\geq 6$ (sexually mature) year olds, respectively. The digestive efficiency, which accounts for the energy lost during digestion, is $94.4 \%$ for female walruses and did not vary significantly across age class or diet (Fisher et al. 1992). Published values of measured digestive efficiencies for pinniped pups consuming milk were not available, but based on the digestive efficiencies of nursing terrestrial animals, it is assumed that nursing pinniped pups lose $5 \%$ of ingested energy in the excretion of urine and feces (Oftedal \& Iverson 1987, Donohue et al. 2002, McDonald et al. 2012). Based on this, and for consistency across age classes, we also used the digestive efficiency of $94.4 \%$ from Fisher et al. (1992) for milk-dependent pups.

\section{Annual cycle}

We estimated daily caloric demands for each day during a year, starting on 1 May (estimated mean birth day based on the range for the birthing period of Pacific walruses described by Fay 1985) and ending on 30 April, corresponding to $t=1, \ldots, 365$. For ages 0 to $11 \mathrm{yr}$, mass $(M)$ was increased at the start of each day by a daily mass increment, which was $1 / 365$ of the difference between the initial mass for that age class and the initial mass for the next age class (i.e. linear increase). This approach adequately captures annual variability in body mass. Other species of pinnipeds show seasonal variability in body mass (northern fur seals Callorhinus ursinus, Trites \& Bigg 1996; Steller sea lions Eumetopias jubatus, Winship et al.
2001), but we were unable to incorporate seasonal variability in body mass due to the lack of such data for walruses. The growth premium $(G)$, which only has values $>1$ for ages $<6 \mathrm{yr}$, was calculated on a daily basis for animals $<6$ yr old in an analogous manner, where $G$ was decreased at the start of each day by a daily growth premium deficit which was $1 / 365$ of the difference between the initial growth premium for that age class and the initial growth premium for the next age class (i.e. linear decrease).

Fay (1982) indicated that the peak annual molting period for Pacific walruses is from July to August and lasts about $1 \mathrm{mo}$, but that the first postpartum molt occurs in June or July about 1 to 2 mo after birth. We approximated this pattern by setting $P_{\mathrm{m}}(t)=1$ for $t=32, \ldots, 61$ ( $30 \mathrm{~d}, 1$ to 30 June) for age 0 and $t=78$, $\ldots, 107$ ( $30 \mathrm{~d}, 17$ July to 15 August) for ages $>0$. Otherwise, $P_{\mathrm{m}}(t)=0$.

Females appear to ovulate principally in January to February; implantation of the blastocyst is delayed until June to July, and calves are born 10-11 mo later, mainly from April to mid-June (Fay 1985). We had no information about the energetic costs of early pregnancy, but most of the costs of pregnancy for an otariid were incurred during the last trimester (Williams et al. 2007). Thus, for females with an embryo in diapause on Day 1, we set $P_{\mathrm{p}}(t)=1$ for $t=260$, ..., 365 (15 January to 30 April), which represented the duration of the last trimester of pregnancy (106 d) and otherwise let $P_{\mathrm{p}}(t)=0$. Walruses nurse their young for up to 2 yr post parturition (Fay 1985), and thus we set $P_{1}(t)=1$ for $t=1, \ldots, 365$ for individuals nursing on Day 1 and $P_{1}(t)=0$ for individuals that were not nursing. Walruses may still be nursing their last calf while they are in their last trimester of pregnancy (Fay 1985). Therefore, we considered cases where females were pregnant on Day 1 but not nursing, nursing but not pregnant, and both pregnant and nursing.

\section{Activity}

We were also interested in exploring how changes in haul-out activity associated with variable sea ice states might impact energetic costs. Udevitz et al. (2009) found that Pacific walruses in the Bering Sea spent about $83 \%$ of their time in water during April. This is consistent with values observed for Atlantic and other Pacific walruses during October to January (Born et al. 2005) and July to September (Born \& Knutsen 1997, Gjertz et al. 2001, Jay et al. 2001, Born et al. 2005, Acquarone et al. 2006, Lydersen et al. 2008), although there are no published data on proportion of 
time in water for walruses at other times of year. Therefore, we used the value from Udevitz et al. (2009) as a base rate, setting $P_{\mathrm{w}}(t)=0.83$ and $P_{\mathrm{h}}(t)=1-$ $P_{\mathrm{w}}(t)=0.17, t=1, \ldots, 365$, to represent behavior when sea ice is available throughout the year (Scenario 1), as was the case for sea ice in previous decades (Douglas 2010). We also considered scenarios where sea ice was not available ('ice-free') for periods of $46 \mathrm{~d}$ (Scenario $2 ; t=116, \ldots, 161,24$ August to 8 October) and $92 \mathrm{~d}$ (Scenario $3 ; t=93, \ldots, 184,1$ August to 31 October). The $46 \mathrm{~d}$ period represents an intermediate value while the $92 \mathrm{~d}$ period is based on models that indicate shelf waters of the Chukchi Sea will be ice-free during at least August, September, and October by the end of the century (Douglas 2010). It was hypothesized that during ice-free periods, walruses may spend more time transiting in water to reach productive foraging areas (Jay et al. 2011). We investigated the cost of this change in behavior by allowing $P_{\mathrm{w}}(t)$ to range as high as 0.93 , the maximum proportion of time in water observed for a free-ranging walrus in the Bering Sea (Udevitz et al. 2009).

\section{Validation}

For our model to be plausible, it must allow walruses to meet their estimated energetic demands by consuming enough prey, given realistic limits to time available for foraging and realistic limits to ingestion. Due to a lack of data for walruses, we were not able to address how mobilization of internal energy stores could support daily energetic demand. The proportion of time required to forage must be considerably less than $83 \%$ of the time (or less than $93 \%$ during ice-free periods) because the proportion of time in water includes all aquatic activity (transit time, other activities, and foraging time). The ingestion rate should be approximately $5-7 \%$ of body mass $\mathrm{d}^{-1}$ to be in agreement with consumption estimates based on stomach contents (Fay 1982) and observations of foraging (Born et al. 2003) for walruses. We assumed the maximum possible rate of ingestion was $15-20 \%$ of body mass $\mathrm{d}^{-1}$ based on observed upper limits to food consumption by Steller sea lions (Rosen 2009). Our estimates of foraging time and biomass consumption were calculated from data based on observations of free-ranging Atlantic walruses Odobenus rosmarus rosmarus (Born et al. 2003). These walruses consumed an average of 8 clams (comprised of $72 \%$ Mya truncata, $21 \%$ Hiatella arctica, and $7 \%$ Serripes groenlandicus) per minute of dive cycle (dive duration plus subsequent surface duration; Born et al.
2003). Based on the energy content of the bivalves collected from the walruses' feeding sites, this consumption rate was equivalent to $92.57 \mathrm{kcal}$ (conversion: $4.184 \mathrm{~kJ}=1 \mathrm{kcal}$ ) or 87.68 shell-free $\mathrm{g}$ wet weight per minute of dive, or $11.57 \mathrm{kcal}$ and 10.96 shell-free $g$ wet weight per bivalve consumed (energy density $=1.06 \mathrm{kcal} \mathrm{g}^{-1}$ or $4.42 \mathrm{~kJ} \mathrm{~g}^{-1}$; Born et al. 2003). Although the diet of Pacific walruses is more diverse (Sheffield \& Grebmeier 2009) than we assumed for validation, walruses are highly selective for bivalves (Fay et al. 1977, Fay \& Lowry 1981, Fay \& Stoker 1982a,b), and the energy contents of diverse taxa of marine benthic invertebrates from the Canadian Arctic are similar (Wacasey \& Atkinson 1987). Nonetheless, the bivalves sampled by Born et al. (2003) were collected in August, the time of peak reproductive activity in Arctic waters (Wacasey \& Atkinson 1987). Thus, the caloric densities may be at the high end of the range (Wacasey \& Atkinson 1987), with the result that the calculated number of clams required to meet energetic demands may represent a minimum number of bivalves. Counteracting this, however, is the possible increase in foraging time required by a strict clam diet. This is because the handling time required for clams may be greater than other soft-bodied benthic invertebrates because walruses must extract the clams from their shells before consuming them. Thus, our foraging time estimates may represent maximum effort.

\section{Elasticity}

We assessed the relative effects of potential errors in parameter values used in the model by calculating the elasticity (e) of mean daily energy requirement to each of these parameters. These elasticities expressed the change in estimated mean daily energy requirement that would result from a given proportional change in each of the parameters. Elasticities were calculated analytically according to Caswell (2001) as:

$$
e_{\theta}=\frac{\theta}{\bar{E}} \frac{\delta \bar{E}}{\delta \theta}
$$

where $\theta$ is the parameter under consideration and $\bar{E}=\left(\sum_{t=1}^{365} E(t)\right) / 365$ is the mean daily energy requirement for a given age and reproductive class of walrus. For parameters with elasticities that depended on the proportion of time in water, we used a value of $P_{\mathrm{w}}(t)=0.83$. For parameters that are constant, the resulting elasticity values are the proportional changes in mean daily energy requirement that would result from changing the given parameters by $1 \%$. For $\theta=$ $M(t)$ or $G(t)$, the values are the proportional change 
resulting from changing these parameters by $1 \%$ of their average values for the year.

\section{RESULTS}

\section{Model}

Across age and reproductive classes, daily caloric needs ranged from 16359 to $137576 \mathrm{kcal} \mathrm{d}^{-1}$ during ice-available years, with larger animals having greater overall daily energetic needs (Fig. 1). The influence of increasing body mass on daily caloric demand was particularly evident in the age- 0 class, which had the fastest growth rate and largest change in caloric demand over the year (Fig. 1). On a mass-specific basis, the youngest age classes (particularly the $0-5 \mathrm{yr}$ olds subject to a growth premium multiplier) had the greatest energetic demand (Table 2). The energetic demand of the molt was apparent on Days 32 to 61 for the young of the year and Days 78 to 107 for $1-12$ yr olds, where there was a $7-12 \%$ increase in daily caloric requirements for nonlactating females (Fig. 1). Reproductive females had the greatest caloric require-

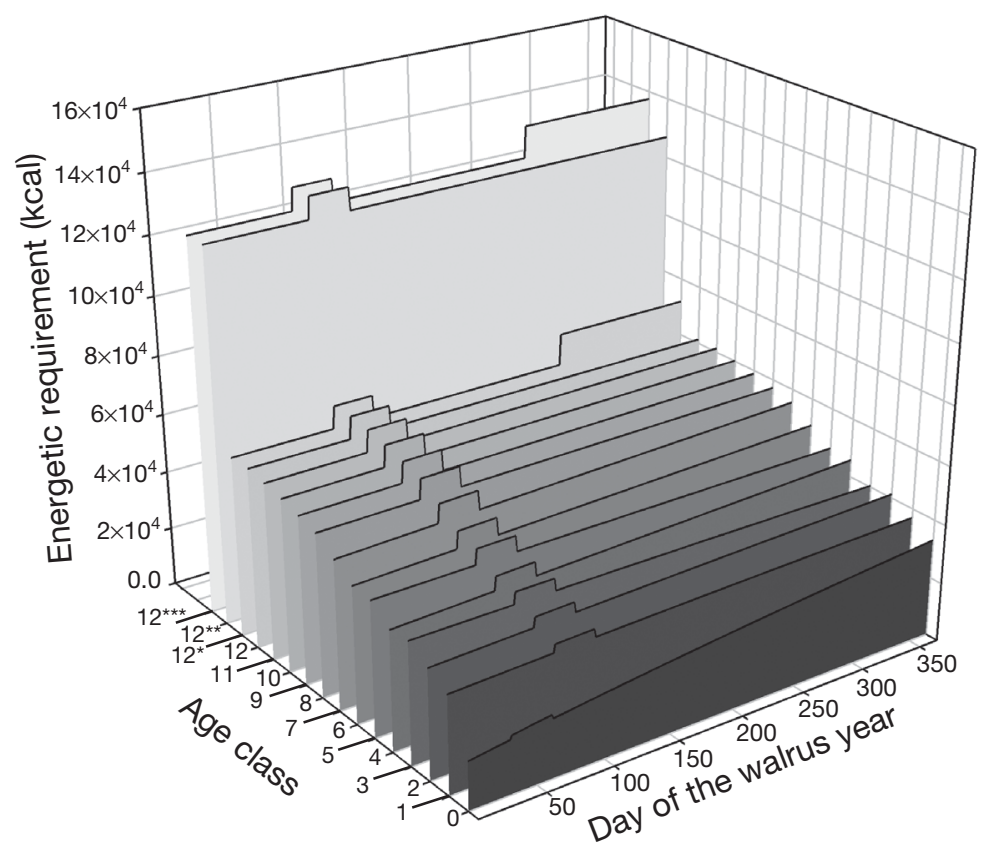

Fig. 1. Odobenus rosmarus divergens. Daily energetic requirements (kcal) of 0 to 12 yr old female Pacific walruses throughout the year when sea ice is available. Energetic demand was based on an activity budget of $83 \%$ of the time active in water and $17 \%$ of the time resting hauled-out, where Day 1 of the walrus year is 1 May (birth date of the animals) and Day 365 is 30 April. The energetic demand of their $30 \mathrm{~d}$ molt is represented by $t=32, \ldots, 61$ ( 1 to 30 June) for the young of the year and by $t=78, \ldots, 107$ (17 July to 15 August) for ages $>0$. The $12 \mathrm{yr}$ age class is represented by 4 different cases, 12 (non-reproductive), 12* (pregnant), 12** (lactating), and $12^{* * *}$ (simultaneously pregnant and lactating), where the energetic demand of pregnancy is during the third trimester $(t=260, \ldots, 365,15$ January to 30 April) and the energetic demand of lactation occurs throughout 2 yr postpartum

Table 2. Odobenus rosmarus divergens. Estimated annual and daily energetic needs for female Pacific walruses spending $83 \%$ of the time in water year-round (Scenario 1). NA: not applicable; P: pregnant; L: lactating

\begin{tabular}{|c|c|c|c|c|c|c|}
\hline $\begin{array}{l}\text { Age class } \\
\text { (mass range } \\
\text { in kg) }\end{array}$ & $\begin{array}{c}\text { Annual } \\
\text { energetic } \\
\text { demand } \\
\text { (kcal) }\end{array}$ & $\begin{array}{c}\text { Daily } \\
\text { energetic } \\
\text { demand } \\
\text { (kcal) }\end{array}$ & $\begin{array}{l}\text { Daily mass- } \\
\text { specific } \\
\text { energetic } \\
\text { demand } \\
\left(\mathrm{kcal} \mathrm{kg}^{-1}\right)\end{array}$ & $\begin{array}{l}\text { Daily clams } \\
\text { consumed } \\
\text { to meet } \\
\text { energetic } \\
\text { demand }\end{array}$ & $\begin{array}{l}\text { Daily clams } \\
\text { consumed as \% } \\
\text { body mass to } \\
\text { meet energetic } \\
\text { demand }\end{array}$ & $\begin{array}{c}\% \text { of day } \\
\text { foraging } \\
\text { to meet } \\
\text { energetic } \\
\text { demand }\end{array}$ \\
\hline $0(65-95)$ & 9368313 & $16359-33113$ & $170-257$ & NA & NA & NA \\
\hline $1(95-270)$ & 12976911 & $33147-37349$ & $137-175$ & NA & NA & NA \\
\hline $2(270-345)$ & 14443101 & $37022-41881$ & $120-145$ & $3200-3620$ & $13-15$ & $28-31$ \\
\hline $3(345-420)$ & 15127583 & $40522-45426$ & $97-126$ & $3502-3926$ & $9-12$ & $30-34$ \\
\hline 4 (420-495) & 15903034 & $40517-46799$ & 93-106 & $3502-4045$ & $9-10$ & $30-35$ \\
\hline $5(495-570)$ & 17007992 & $45830-51389$ & $81-100$ & $3961-4442$ & $8-10$ & $34-39$ \\
\hline $6(570-645)$ & 17903102 & $46314-53507$ & $79-91$ & $4003-4625$ & $8-9$ & $35-40$ \\
\hline $7(645-725)$ & 19590718 & $50813-58612$ & $77-88$ & $4392-5066$ & $7-8$ & $38-44$ \\
\hline $8(725-755)$ & 20765514 & $55470-62869$ & $76-86$ & $4794-5434$ & $7-8$ & $42-47$ \\
\hline $9(755-785)$ & 21393870 & $57183-64787$ & $75-85$ & $4942-5600$ & $7-8$ & $43-49$ \\
\hline $10(785-810)$ & 21964971 & $58878-66595$ & $74-84$ & $5089-5756$ & $7-8$ & $44-50$ \\
\hline $11(810-830)$ & 22428648 & $60279-68074$ & $74-84$ & $5210-5884$ & $7-8$ & $45-51$ \\
\hline $12(830)$ & 22635120 & $61392-68960$ & $74-83$ & $5306-5960$ & $7-8$ & $46-52$ \\
\hline $12 \mathrm{P}(830)$ & 23758190 & $61392-71987$ & $74-87$ & $5306-6222$ & $7-8$ & $46-54$ \\
\hline $12 \mathrm{~L}(830)$ & 46575105 & $126981-134549$ & $153-162$ & $10975-11629$ & 15 & 95-101 \\
\hline 12 P\&L (830) & 47698175 & $126981-137576$ & $153-166$ & $10975-11891$ & $15-16$ & $95-103$ \\
\hline
\end{tabular}



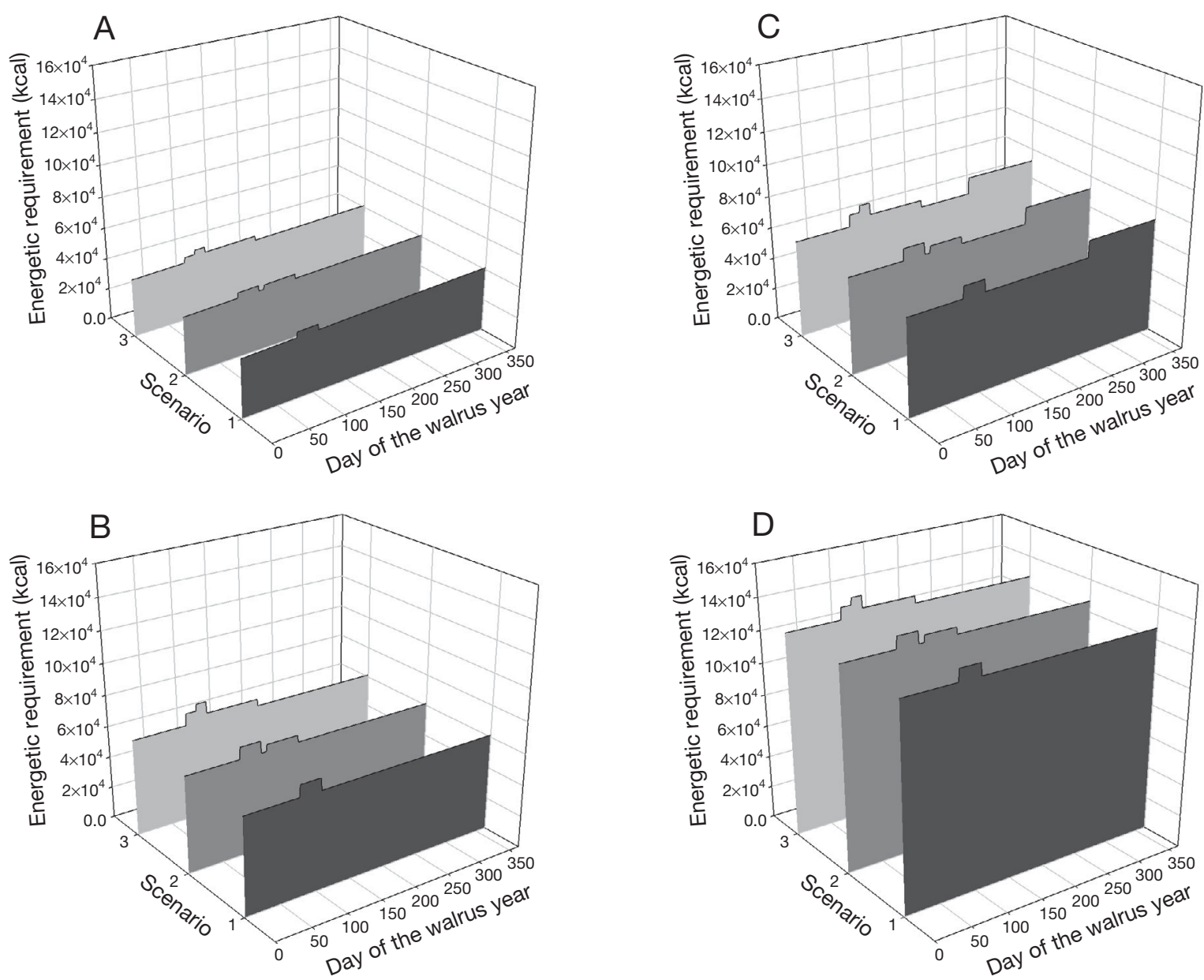

Fig. 2. Odobenus rosmarus divergens. Daily energetic requirements (kcal) of female Pacific walruses throughout the year assuming 3 different sea ice scenarios. Energetic demand was based on an activity budget of $83 \%$ of the time active in water and $17 \%$ of the time resting hauled-out yearround (Scenario 1). The proportion of time in water was then increased to $93 \%$ for ice-free periods of 46 (Scenario 2, $t=$ $116, \ldots, 161,24$ August to 8 October) and 92 (Scenario 3, $t=$ $93, \ldots, 184,1$ August to 31 October) days from late summer to early fall, where Day 1 of the walrus year is 1 May (birth date of the animals) and Day 365 is 30 April. A subset of the age and reproductive classes is provided: (A) $2 \mathrm{yr}$, (B) $12 \mathrm{yr}$, (C) 12 yr pregnant, (D) 12 yr lactating, (E) 12 yr simultaneously pregnant and lactating, where the energetic demand of pregnancy is during the third trimester $(t=260, \ldots, 365,15$ January to 30 April) and the energetic demand of lactation occurs throughout 2 yr postpartum

ments, with the third trimester of pregnancy and lactation in 12 yr old walruses resulting in a 17 and $107 \%$ increase in daily caloric requirements from non-reproductive levels, respectively (Fig. 1).

Changes in the duration of the ice-free period, and hence the proportion of time in water, also impacted daily caloric requirements (Fig. 2). Although there was less than a $1 \%$ difference in annual energy

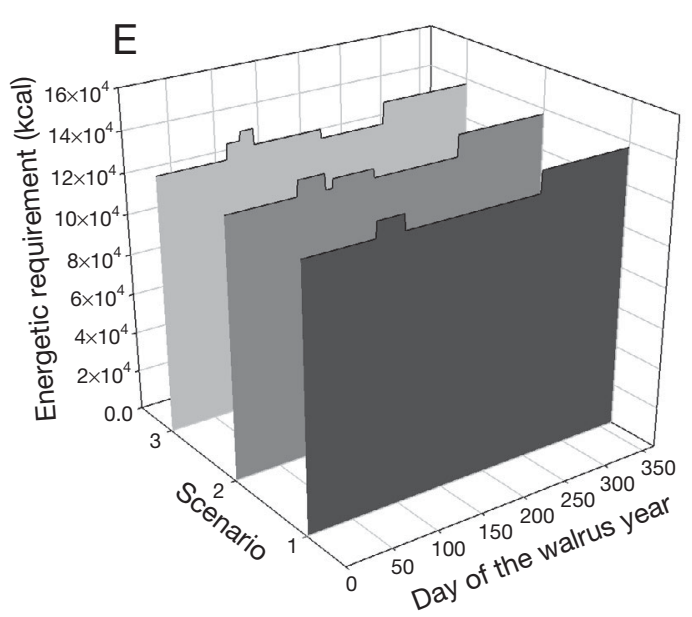

demand across the 3 ice scenarios (Tables 2 to 4 ), daily energy requirements increased by $6-7 \%$ for 0 to $12 \mathrm{yr}$ old non-lactating females when the proportion of time in water increased from 83 to $93 \%$ of the time during 24 August to 8 October (Scenario 2) and 1 August to 31 October (Scenario 3; Fig. 2). The caloric demand of lactation minimized the signal associated with variable activity budgets; daily caloric 
Table 3. Odobenus rosmarus divergens. Estimated annual and daily energetic needs for female Pacific walruses spending $83 \%$ of the time in water when sea ice is available and $93 \%$ of the time in water for $46 \mathrm{~d}$ of the year when sea ice is not available (24 August to 8 October) (Scenario 2). NA: not applicable; P: pregnant; L: lactating

\begin{tabular}{|c|c|c|c|c|c|c|}
\hline $\begin{array}{l}\text { Age class } \\
\text { (mass range } \\
\text { in kg) }\end{array}$ & $\begin{array}{c}\text { Annual } \\
\text { energetic } \\
\text { demand } \\
\text { (kcal) }\end{array}$ & $\begin{array}{c}\text { Daily } \\
\text { energetic } \\
\text { demand } \\
\text { (kcal) }\end{array}$ & $\begin{array}{l}\text { Mass- } \\
\text { specific } \\
\text { energetic } \\
\text { demand } \\
\left(\mathrm{kcal} \mathrm{kg}^{-1}\right)\end{array}$ & $\begin{array}{c}\text { Daily clams } \\
\text { consumed } \\
\text { to meet } \\
\text { energetic } \\
\text { demand }\end{array}$ & $\begin{array}{l}\text { Daily clams } \\
\text { consumed as \% } \\
\text { body mass to } \\
\text { meet energetic } \\
\text { demand }\end{array}$ & $\begin{array}{c}\% \text { of day } \\
\text { foraging } \\
\text { to meet } \\
\text { energetic } \\
\text { demand }\end{array}$ \\
\hline $0(65-95)$ & 9446267 & $16359-33113$ & $170-257$ & NA & NA & NA \\
\hline $1(95-270)$ & 13091047 & $33147-37714$ & $137-175$ & NA & NA & NA \\
\hline $2(270-345)$ & 14569826 & $37022-41881$ & $120-145$ & $3200-3620$ & $13-15$ & $28-31$ \\
\hline $3(345-420)$ & 15262378 & $40522-45426$ & $97-126$ & $3502-3926$ & $9-12$ & $30-34$ \\
\hline $4(420-495)$ & 16041934 & $40517-46799$ & $93-106$ & $3502-4045$ & $9-10$ & $30-35$ \\
\hline $5(495-570)$ & 17158637 & $45830-51389$ & $81-100$ & $3961-4442$ & $8-10$ & $34-39$ \\
\hline $6(570-645)$ & 18059900 & $46314-53507$ & $79-91$ & $4003-4625$ & $8-9$ & $35-40$ \\
\hline $7(645-725)$ & 19762394 & $50813-58612$ & $77-88$ & $4392-5066$ & $7-8$ & $38-44$ \\
\hline $8(725-755)$ & 20948727 & $55470-62869$ & $76-86$ & $4794-5434$ & $7-8$ & $42-47$ \\
\hline $9(755-785)$ & 21582657 & $57183-64787$ & $75-85$ & $4942-5600$ & $7-8$ & $43-49$ \\
\hline $10(785-810)$ & 22158926 & $58878-66595$ & $74-84$ & $5089-5756$ & $7-8$ & $44-50$ \\
\hline $11(810-830)$ & 22626821 & $60279-68074$ & $74-84$ & $5210-5884$ & $7-8$ & $45-51$ \\
\hline $12(830)$ & 22835542 & $61392-68960$ & $74-83$ & $5306-5960$ & $7-8$ & $46-52$ \\
\hline $12 \mathrm{P}(830)$ & 23958612 & $61392-71987$ & $74-87$ & 5306-6222 & $7-8$ & $46-54$ \\
\hline $12 \mathrm{~L}(830)$ & 46775527 & $126981-134549$ & $153-162$ & $10975-11629$ & 15 & $95-101$ \\
\hline 12 P\&L (830) & 47898597 & $126981-137576$ & $153-166$ & $10975-11891$ & $15-16$ & $95-103$ \\
\hline
\end{tabular}

Table 4. Odobenus rosmarus divergens. Estimated annual and daily energetic needs for female Pacific walruses spending $83 \%$ of the time in water when sea ice is available and $93 \%$ of the time in water for $92 \mathrm{~d}$ of the year when sea ice is not available (1 August to 31 October) (Scenario 3). NA: not applicable; P: pregnant; L: lactating

\begin{tabular}{|c|c|c|c|c|c|c|}
\hline $\begin{array}{l}\text { Age class } \\
\text { (mass range } \\
\text { in kg) }\end{array}$ & $\begin{array}{c}\text { Annual } \\
\text { energetic } \\
\text { demand } \\
\text { (kcal) }\end{array}$ & $\begin{array}{c}\text { Daily } \\
\text { energetic } \\
\text { demand } \\
\text { (kcal) }\end{array}$ & $\begin{array}{l}\text { Mass- } \\
\text { specific } \\
\text { energetic } \\
\text { demand } \\
\left(\mathrm{kcal} \mathrm{kg}^{-1}\right)\end{array}$ & $\begin{array}{l}\text { Daily clams } \\
\text { consumed } \\
\text { to meet } \\
\text { energetic } \\
\text { demand }\end{array}$ & $\begin{array}{l}\text { Daily clams } \\
\text { consumed as \% } \\
\text { body mass to } \\
\text { meet energetic } \\
\text { demand }\end{array}$ & $\begin{array}{c}\% \text { of day } \\
\text { foraging } \\
\text { to meet } \\
\text { energetic } \\
\text { demand }\end{array}$ \\
\hline $0(65-95)$ & 9524080 & $16359-33113$ & $170-257$ & NA & NA & NA \\
\hline $1(95-270)$ & 13205142 & 33 147-39 804 & $137-185$ & NA & NA & NA \\
\hline $2(270-345)$ & 14696536 & $37022-44608$ & $120-154$ & $3200-3856$ & $13-16$ & $28-34$ \\
\hline $3(345-420)$ & 15397148 & $40522-48359$ & $97-133$ & $3502-4180$ & $9-13$ & $30-36$ \\
\hline $4(420-495)$ & 16180829 & $40517-49785$ & $93-113$ & $3502-4303$ & $9-11$ & $30-37$ \\
\hline $5(495-570)$ & 17309268 & $45830-54660$ & $81-106$ & $3961-4724$ & $8-10$ & $34-41$ \\
\hline $6(570-645)$ & 18216691 & $46314-56888$ & $79-96$ & $4003-4917$ & $8-9$ & $35-43$ \\
\hline $7(645-725)$ & 19934069 & $50813-62315$ & $77-93$ & $4392-5386$ & $7-9$ & $38-47$ \\
\hline $8(725-755)$ & 21131945 & $55470-66841$ & $76-91$ & $4794-5777$ & $7-9$ & $42-50$ \\
\hline $9(755-785)$ & 21771432 & $57183-68880$ & $75-90$ & $4942-5953$ & $7-9$ & $43-52$ \\
\hline $10(785-810)$ & 22352884 & $58878-70803$ & $74-89$ & $5089-6120$ & $7-9$ & $44-53$ \\
\hline $11(810-830)$ & 22824996 & $60279-72375$ & $74-89$ & $5210-6255$ & $7-8$ & $45-54$ \\
\hline $12(830)$ & 23035964 & $61392-73317$ & $74-88$ & $5306-6337$ & $7-8$ & $46-55$ \\
\hline $12 \mathrm{P}(830)$ & 24159034 & $61392-73317$ & $74-88$ & $5306-6337$ & $7-8$ & $46-55$ \\
\hline $12 \mathrm{~L}(830)$ & 46975949 & $126981-138906$ & $153-167$ & $10975-12006$ & $15-16$ & $95-104$ \\
\hline 12 P\&L (830) & 48099019 & $126981-138906$ & $153-167$ & $10975-12006$ & $15-16$ & $95-104$ \\
\hline
\end{tabular}

demand of 12 yr old lactating females only increased by $3 \%$ as the proportion of time in water increased (Fig. 2). Nonetheless, the timing and duration of the sea ice-free period was important because increased energetic demands associated with increased time in water is additive when it overlaps with other ener- getically demanding life history stages, particularly the molt and lactation (Fig. 2). Effects on annual caloric demand became more important as the duration of the ice-free period increased and the proportion of time spent in the water increased to its maximum potential value (Fig. 3). 


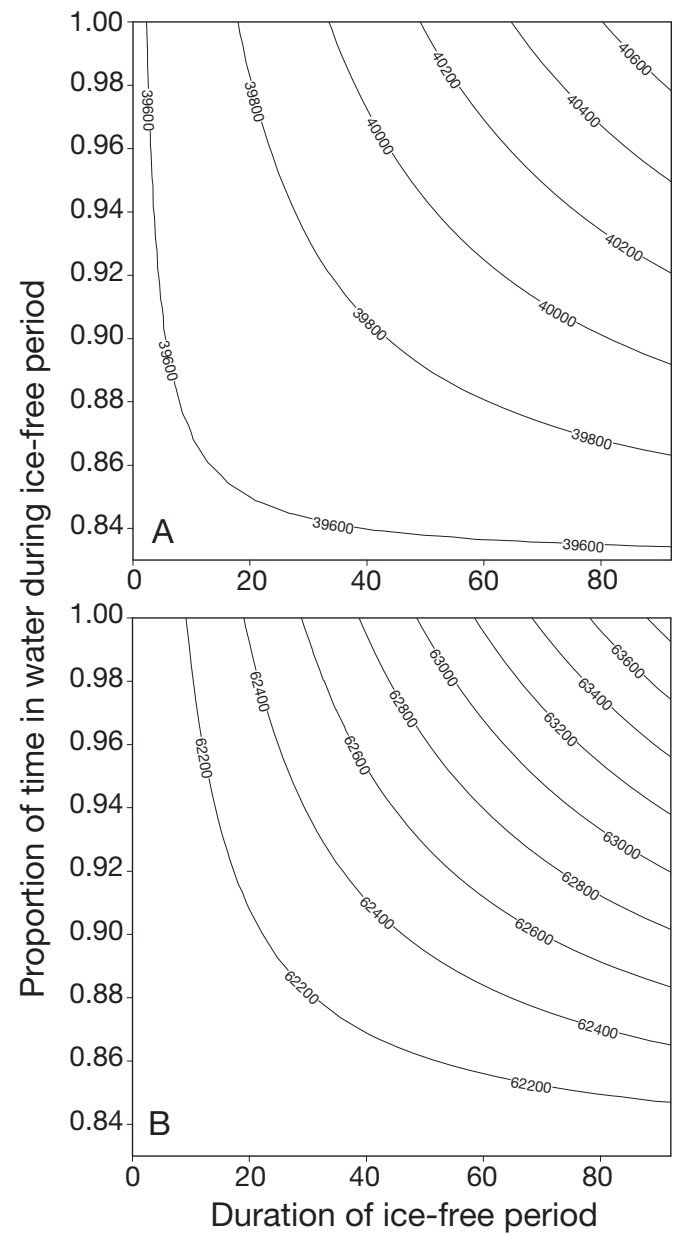

Fig. 3. Odobenus rosmarus divergens. Average daily energetic requirement (kcal) of female Pacific walruses as a function of the proportion of time in water during ice-free periods and the duration of the ice-free period. A subset of the age and reproductive classes is provided: (A) $2 \mathrm{yr}$, (B) $12 \mathrm{yr},(\mathrm{C}) 12 \mathrm{yr}$ pregnant, (D) 12 yr lactating, (E) 12 yr simultaneously pregnant and lactating

\section{Validation}

The predicted energetic requirements of mature ( $\geq 6 \mathrm{yr}$ old), 570-830 kg non-reproductive walruses were in agreement with estimates from other studies. Daily energy requirements during an ice-available year (46314-68960 kcal d ${ }^{-1}$ ) fell within the range of calories consumed $\left(22500-70300 \mathrm{kcal} \mathrm{d}^{-1}\right)$ by $250-$

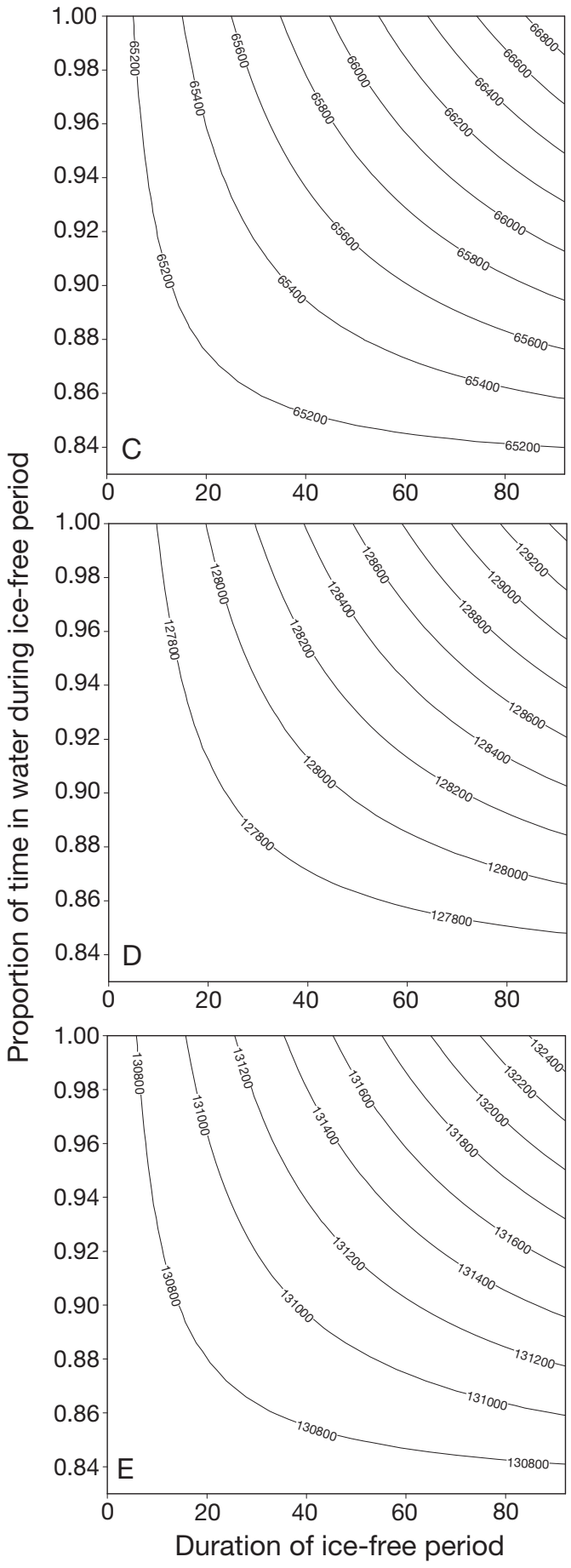

$1200 \mathrm{~kg}$ captive walruses (Fay 1982, Gehnrich 1984, Fisher et al. 1992, Kastelein et al. 2000). In contrast, the estimated daily energy requirements for the young of the year (age-0 class; $16359-33113 \mathrm{kcal} \mathrm{d}^{-1}$ ) were nearly double that of a 10-12 mo old captive walrus fed formula (approximately $11000-14000 \mathrm{kcal}$ $\mathrm{d}^{-1}$ estimated from Figs. $4 \& 5$ in Kastelein et al. 2003) and the estimated energy requirements for $2-4 \mathrm{yr}$ 
olds were more than $10000 \mathrm{kcal} \mathrm{d}^{-1}$ over intake rates for a captive female walrus followed longitudinally from 2 to 4 yr postpartum (Gehnrich 1984).

Nonetheless, the estimated daily caloric requirements (range: 37022-73317 $\mathrm{kcal} \mathrm{d}^{-1}$ ) for milkindependent, non-reproductive female walruses aged $2-12$ yr across all 3 sea ice scenarios could be met within our assumed limits to proportion of time foraging $(<83-93 \%)$ and ingestion rate $(\leq 15-20 \%$ of body mass $\mathrm{d}^{-1}$ ) based on a clam diet. Daily energetic demands were met by foraging $28-55 \%$ of the day and consuming $7-16 \%$ of body mass in clams per day (Tables 2 to 4$)$. In fact, ingestion rates ( $7-9 \%$ of body mass $\mathrm{d}^{-1}$ ) for sexually mature walruses $\geq 6 \mathrm{yr}$ were similar to previous estimates for wild mature Atlantic (Born et al. 2003) and Pacific (Fay 1982) walruses based on underwater observations of clam consumption and analyses of stomach contents, respectively. We did not estimate foraging time or clam consumption for the 0 and $1 \mathrm{yr}$ age classes (Tables 2 to 4 ) because these animals are milk-dependent to varying degrees through 2 yr postpartum (Fay 1985), and without empirical data we cannot estimate the contribution of clams to their daily caloric need.

The ability of reproductive female walruses to meet caloric requirements within our criteria was dependent on the stage of reproduction. Across all 3 sea ice scenarios, $12 \mathrm{yr}$ old pregnant females met daily caloric demand by foraging $46-55 \%$ of the time and consuming $7-8 \%$ of body mass in clams per day (Tables 2 to 4 ). Lactating and simultaneously pregnant and lactating females, however, required consumption rates approaching our upper limit to ingestion $(15-16 \%$ of body mass in clams per day) and required $95-104 \%$ of the time for foraging to meet daily energetic needs, which is not possible.

\section{Elasticity}

Elasticities to model parameters spanned nearly 2 orders of magnitude, ranging from $<0.01$ to 1.00 (Table 5). For non-reproductive walruses, elasticities to digestive efficiency $(D)$, growth premium $(G[t])$, and cost of activity in water $\left(C_{\mathrm{w}}\right)$ had values close to unity and were larger than elasticities to any other parameters. Elasticity to mass $(M[t])$ was also relatively high. Elasticities to $D$ and $M(t)$ remained unchanged for reproductive walruses, but elasticity to $C_{\mathrm{w}}$ was reduced during lactation, when elasticities to both $C_{\mathrm{w}}$ and $C_{\mathrm{l}}$ were about half the elasticity to $D$. Elasticities to the other metabolic cost parameters $\left(C_{\mathrm{h}}, C_{\mathrm{p}}\right.$, and $\left.C_{\mathrm{m}}\right)$ were relatively negligible regardless of reproductive status.
Table 5. Odobenus rosmarus divergens. Elasticities of mean annual energy requirements to bioenergetic parameters for walruses where $D$ is the digestive efficiency, $M(t)$ is the mass on day $t, C_{\mathrm{l}}$ is the cost of lactation, $G(t)$ is the growth premium, $C_{\mathrm{w}}$ is the cost of being active in water, $C_{\mathrm{h}}$ is the cost of resting while hauled out, $C_{\mathrm{p}}$ is the cost of pregnancy, and $C_{\mathrm{m}}$ is the cost of molting

\begin{tabular}{|lcc|}
\hline \multirow{2}{*}{ Parameter } & \multicolumn{2}{c|}{ Elasticity } \\
& Non-reproductive & Pregnant and nursing \\
\hline$D$ & 1.00 & 1.00 \\
$M(t)$ & $0.75^{\mathrm{a}}$ & 0.75 \\
$C_{\mathrm{l}}$ & - & 0.50 \\
$G(t)$ & 0.99 & - \\
$C_{\mathrm{w}}$ & 0.92 & 0.44 \\
$C_{\mathrm{h}}$ & 0.07 & 0.03 \\
$C_{\mathrm{p}}$ & - & 0.02 \\
$C_{\mathrm{m}}$ & 0.01 & 0.00 \\
${ }^{\mathrm{a}}$ Mean value for ages $0-12 ;$ this was the only parameter \\
with age-dependent elasticities (see 'Results') \\
\hline
\end{tabular}

\section{DISCUSSION}

Estimating the daily energy requirements of marine mammals is difficult. Metabolic rates are influenced by activity level, age (and hence growth), body size, molt (for pinnipeds), reproductive status, and environmental conditions (Kleiber 1975, Costa et al. 1986, Costa 2002, Noren 2002, Williams et al. 2007). Bioenergetic modeling is a flexible technique for estimating food consumption of wild pinnipeds because it can account for the influence of some of these factors (Winship et al. 2006). Here we present a bioenergetics model that provides estimates of the energetic demands of female Pacific walruses per a given age and reproductive class. This model estimates the metabolic costs of growth and activity (active in water or hauled-out resting) based on walrus-specific field metabolic rates (direct measurement of whole animal metabolism; Acquarone et al. 2006) and observed activity budgets of walruses in the Bering Sea (Udevitz et al. 2009).

We assessed the relative effects of potential errors in the parameter values used in the model (see parameter value section in the 'Materials and methods' and Table 1) by calculating the elasticity of mean daily energy requirement to each of these parameters. This elasticity analysis indicated that potential errors in values for digestive efficiency $(D)$, the growth premium $(G[t]$, for juveniles), and cost of activity in water $\left(C_{\mathrm{w}}\right)$ would have the most serious effects on our estimates of energy requirements (Table 5). Nonetheless, the value we used for $D$ was based on direct measurements of digestive efficiency 
in female walruses, which did not vary by diet or age (Fisher et al. 1992), and is consistent with the high efficiencies reported for various carnivorous mammals (see Table 3.5 in Blaxter 1989; see Table 4 in Lavigne et al. 1982), as well as for other pinniped species, which ranged from 90.4 to $97 \%$ when fed diets of clams, squid, or various fish (see Table 3 in Rosen \& Trites 2000). Values for $G(t)$ were based on direct measurements of metabolism from immature harp Phoca groenlandica and gray Halichoerus grypus seals (Worthy 1987) because this type of data was not available for immature odobenids or otariids. Future research should focus on obtaining walrus-specific measurements of metabolism throughout ontogeny, even though errors in this parameter will only affect caloric requirement estimates for walruses $<6 \mathrm{yr}$ old. The parameters $C_{\mathrm{h}}$ and $C_{\mathrm{w}}$ entered the model symmetrically; elasticity to $C_{\mathrm{h}}$ was less than the elasticity to $C_{\mathrm{w}}$ only because we set the proportion of time in water, $P_{\mathrm{w}}(t)=0.83$ for these analyses. Elasticity to $C_{\mathrm{h}}$ would increase with a corresponding decrease in the elasticity to $C_{\mathrm{w}}$ as the proportion of time in water decreased. Errors in values for these parameters will be most important for non-lactating females. In any case, the value we used for $C_{\mathrm{w}}$ was based on direct field metabolic rate measurements from walruses (Acquarone et al. 2006), and this value as well as the value for $C_{\mathrm{h}}$ (Table 1) were within the range of field (5-6 times Kleiber-predicted basal metabolic rate [BMR]; Costa et al. 1991, Costa \& Williams 1999, Costa 2002) and maintenance (1.4-2.8 times Kleiberpredicted $\mathrm{BMR}_{i}$ for review see Williams et al. 2001) metabolisms measured directly from a range of pinniped species, which suggests they are robust. Elasticities to mass $(M[t])$ and lactation costs $\left(C_{1}\right)$ were lower than those to $D$ and $G(t)$, but still non-negligible relative to elasticities associated with other parameters. Values for $M(t)$ were based on data from Pacific walruses (Fay 1982), but do not reflect seasonal fluctuations. However, because energy gained during one period is expended in another (Winship et al. 2002), this should not affect estimates of annual energy requirements. Our value for $C_{1}$ was based on food consumption of wild, lactating California sea lions temporarily under human care (Williams et al. 2007), but this value is also consistent with levels of intake reported for other lactating mammals, including domestic dogs Canis familiaris (Case 1999), freeranging African lions Panthera leo (Schaller 1972), and Antarctic fur seals Arctocephalus gazella (Costa et al. 1989).

As would be expected due to the mass-related scaling of metabolism and the influence of growth on metabolism (Kleiber 1975), daily energy demand on average over the year across non-reproductive walruses was approximately 2 times greater in the oldest (largest) walruses compared to age- 0 walruses, while mass-specific daily energy demand was nearly 3 times greater for age- 0 walruses compared to $\geq 6 \mathrm{yr}$ old age classes that were approaching the asymptote for mature body mass. Daily consumption of clams on average over the year declined with the size of the walrus from 14 to $7 \%$ of body mass $\mathrm{d}^{-1}$ for non-reproductive 2-12 yr old females. These differences highlight the vulnerability of the youngest age classes during food-limited periods because they must acquire proportionally greater amounts of prey. At the same time, the youngest age classes of walruses may be similar to other young pinnipeds in that small body size combined with underdeveloped diving physiology limits foraging capabilities (for review see Noren et al. 2005). These factors combined may explain the disproportionate deleterious effects on juveniles during prey-limited periods (DeLong et al. 1991).

In addition to the influence of body size and growth on caloric requirements, certain life history stages induce additional energetic demands. One of these stages for pinnipeds is the molt. Until recently, the cost of pinniped molting was considered to be low (Ashwell-Erickson \& Elsner 1981, Worthy et al. 1992), and as a result these costs were not included in most bioenergetics models (i.e. Olesiuk 1993, Mohn \& Bowen 1996, Stenson et al. 1997, Winship et al. 2002). However, a recent study on California sea lions demonstrated that resting metabolism increased by 1.3 times during the molt (Williams et al. 2007). Using this value in our model, we estimated that the annual $30 \mathrm{~d}$ molt (Fay 1982) of a $12 \mathrm{yr}$ old female costs a total of 227040 extra kilocalories. Although this only accounts for $1 \%$ of the animal's total annual energetic requirements, it translates into an energetic demand of nearly 20000 extra clams to sustain the cost of the molt. Although walruses in captivity generally consume less during the molt than at other times (Gehnrich 1984, Dittrich 1987, Kastelein et al. 2000), radio-tracking of Pacific walruses indicates that foraging behavior is ongoing during the molt period (USGS, Alaska Science Center unpubl. data). If endogenous reserves (i.e. blubber) are not increased outside of the molting period to compensate for this increased energetic burden, aggregations of highly gregarious molting walruses may have a negative short-term impact on localized prey resources.

Reproduction has also been largely ignored in bioenergetic estimates for pinnipeds (Olesiuk 1993, 
Mohn \& Bowen 1996, Stenson et al. 1997) with the exception of a bioenergetics model for Steller sea lions (Winship et al. 2002). Although measurements of resting metabolism were similar for non-lactating and lactating fur seals (Costa \& Gentry 1986) as well as for non-reproductive, pregnant, and lactating California sea lions (Williams et al. 2007), food consumption was greater in the lactating fur seals (Costa et al. 1989) and later-stage pregnant and lactating California sea lions (Williams et al. 2007) compared to their non-reproductive counterparts. For example, food consumption increased substantially within the first few days of lactation and was maintained at a consistently high level until 2 wk after weaning (Williams et al. 2007, T.M. Williams pers. comm.). Indeed, food intake was $11 \%$ (Costa et al. 1991) and $5 \%$ (Winship et al. 2006) of body mass $\mathrm{d}^{-1}$ for lactating and non-lactating California sea lions, respectively. Thus, during reproduction there can be a mismatch where an increase in food consumption is not reflected by the measured metabolism (Williams et al. 2007). Pinnipeds are similar to other mammals, where there is little additional metabolic cost to milk synthesis but lactation is fueled by greater caloric intake (Hammond \& Diamond 1992). As with other pinnipeds, marked increases in food consumption have been observed for pregnant and lactating captive walruses. Females consumed 30-40\% more food when pregnant and 50-101\% more food when lactating compared to non-reproductive periods, while simultaneously lactating and pregnant females were estimated to increase food consumption by 90-130\% (Gehnrich 1984, Kastelein et al. 2000).

In our model, the effect of reproduction had a pronounced impact on estimated caloric requirements (Fig. 1) and the time that the animal must allocate to foraging to meet these demands (Table 2). For example, during each day of the last trimester, an $830 \mathrm{~kg}$ $12 \mathrm{yr}$ old female had an extra energetic burden of $10595 \mathrm{kcal} \mathrm{d}^{-1}$. For walruses, the third trimester lasts approximately $106 \mathrm{~d}$, thus the total energetic burden of pregnancy (assuming there are no costs during the first and second trimesters) for a 12 yr old female is $1123070 \mathrm{kcal}$, equivalent to nearly 100000 clams. The caloric demand of a lactating 12 yr old walrus during an ice-available year (83\% of time in water year-round) doubled from non-reproductive levels, with the result that corresponding clam consumption doubled from $7-8 \%$ to $15 \%$ of body mass $d^{-1}$ and the estimated proportion of time required to forage increased from $46-52 \%$ to $95-101 \%$ of the time (or $95-103 \%$ of the time when the animal was simultaneously pregnant and lactating; Table 2). Clearly, proportions of time spent foraging $>83 \%$ are not possible, given our baseline assumption that walruses only spend a total of $83 \%$ of their time in the water. Undoubtedly some of the energetic demand of lactation is met by utilizing endogenous energy reserves (e.g. blubber), which is consistent with the observation that blubber thickness varies with reproductive condition in female walruses (Fay 1985). Changes in lipid stores and the blubber layer have also been associated with the demands of lactation in California sea lions (Williams et al. 2007).

Walruses likely undergo periods of weight gain to build up energy stores and subsequently lose weight during other periods, such as during the breeding season and molt as is evident in other pinnipeds, particularly phocids (Chabot et al. 1996). Captive female walruses have been observed to fast briefly, and their food consumption rates are known to vary seasonally (Kastelein et al. 2000). It has been suggested that Pacific walruses eat little on their northward spring migration (Fay 1982) while summer (July to September) and autumn (October to December) migrations are marked by high food intake (Fay 1985). However, recent radio-tracking studies indicate that walruses do forage during the spring migration (USGS, Alaska Science Center unpubl. data). Detailed data on the body condition of female walruses across reproductive stages and seasons are not available, thus further research is necessary before we can allocate differential food intake rates across seasons. If there are intermittent periods of fasting and subsequent periods of excessive consumption to bolster lipid storage, food consumption and caloric requirements may be uncoupled on a daily basis such that daily calories consumed will be more variable than those estimated by our model. Nonetheless, on an annual basis, food consumption must equal caloric requirements because energy gained during one period is expended in another (Winship et al. 2002).

Although caloric requirements associated with basic physiology of walruses are unlikely to change, caloric requirements may change as behavior is altered in response to environmental change. For example, environmentally induced changes in haulout behavior could alter energy requirements of walruses (Fay \& Ray 1968). If walruses continue to increase utilization of terrestrial haul-outs as seasonal sea ice availability in the Chukchi Sea decreases (Douglas 2010), they may spend greater amounts of time in water actively transiting to productive foraging areas (Jay et al. 2011). In our model, when the proportion of time in water was increased from 83 to $93 \%$ of the time during ice-free periods, daily energy 
requirements increased by $6-7 \%$ for $0-12$ yr old non-lactating female walruses (Tables 2 to 4 ). The timing of the sea ice-free period is also important because the increased energetic demands of increased time in water associated with ice-free periods can overlap with energetically costly life history stages, such as the molt, pregnancy, and lactation. Considering that walruses are gregarious on terrestrial haul-outs, the increased energetic requirement at the population level could have an impact on localized prey resources, where they might not be able to sustain the energetic demands of walruses during sea ice-free periods.

Our model provides the first bioenergetics-based estimates of energy requirements for Pacific walruses, and includes an estimate of the effect on energetic requirements that could result from potential haul-out behavior changes in response to seasonal reductions in sea ice. Unlike most bioenergetics models for pinnipeds (e.g. Olesiuk 1993, Mohn \& Bowen 1996, Stenson et al. 1997), ours incorporates costs of reproduction and molting, which can be substantial. Still, the model is, of necessity, relatively simple because of the lack of data on walrus physiology required to support a more complex model. Estimates of parameters in the current model may be improved by obtaining species-specific data on seasonal variation in food consumption and body condition to support extensions to account for seasonal variations in the acquisition, use, and storage of energy by walruses. These types of extensions, in combination with more detailed accounts of the variation in activity throughout the year (proportion of time in water and time hauled out), could support bioenergetic linkages between prey distribution and walrus demography that can ultimately be used for predicting population responses to their changing environment.

Acknowledgements. We thank T. M. Williams for insightful discussions regarding the costs of reproduction in pinnipeds and B. Fadely for helpful comments on a previous version of this manuscript. Any mention of trade names is for descriptive purposes only and does not constitute endorsement by the US federal government.

\section{LITERATURE CITED}

Acquarone M, Born EW, Speakman JR (2006) Field metabolic rates of walrus (Odobenus rosmarus) measured by the doubly labeled water method. Aquat Mamm 32: 363-369

Agnarsson I, Kuntner M, May-Collado LJ (2010) Dogs, cats, and kin: a molecular species-level phylogeny of Carnivora. Mol Phylogenet Evol 54:726-745
Arim M, Naya DE (2003) Pinniped diets inferred from scats: analysis of biases in prey occurrence. Can J Zool 81: $67-73$

Ashwell-Erickson S, Elsner R (1981) The energy cost of free existence for Bering Sea harbor and spotted seals. In: Hood DW, Calder JA (eds) The Eastern Bering Sea shelf: oceanography and resources, Vol 2. University of Washington Press, Seattle, WA, p 869-899

Blaxter K (1989) Energy metabolism in animals and man. Cambridge University Press, Cambridge

Born EW, Knutsen LØ (1997) Haul-out and diving activity of male Atlantic walruses (Odobenus rosmarus rosmarus) in NE Greenland. J Zool (Lond) 243:381-396

Born EW, Rysgaard S, Ehlmé G, Sejr M, Acquarone M, Levermann N (2003) Underwater observations of foraging free-living Atlantic walrus (Odobenus rosmarus rosmarus) and estimates of their food consumption. Polar Biol 26:348-357

Born EW, Acquarone M, Knutsen LØ, Toudal L (2005) Homing behavior in the Atlantic walrus (Odobenus rosmarus rosmarus). Aquat Mamm 31:23-33

Case LP (1999) The dog: its behavior, nutrition and health. Iowa State University Press, Ames, IA

Caswell H (2001) Matrix population models, 2nd edn. Sinauer Associates, Sunderland, MA

Chabot D, Stenson GB, Cadigan NB (1996) Short- and longterm fluctuations in the size and condition of harp seal (Phoca groenlandica) in the Northwest Atlantic. Sci Counc Stud NAFO 26:15-32

Costa DP (2002) Energetics. In: Perrin WF, Würsig B, Thewissen JGM (eds) Encylopedia of marine mammals. Academic Press, San Diego, CA, p 387-394

Costa DP, Gentry RL (1986) Free-ranging energetics of northern fur seals. In: Gentry RL, Kooyman GL (eds) Fur seals: maternal strategies on land and at sea. Princeton University Press, Princeton, NJ, p 79-101

Costa DP, Williams TM (1999) Marine mammal energetics. In: Reynolds JE III, Rommel SA (eds) Biology of marine mammals. Smithsonian Institution Press, Washington, DC, p 176-217

Costa DP, LeBoeuf BJ, Huntley AC, Ortiz CL (1986) The energetics of lactation in the Northern elephant seal, Mirounga angustirostris. J Zool 209:21-33

Costa DP, Croxall JP, Duck CD (1989) Foraging energetics of Antarctic fur seals in relation to changes in prey availability. Ecology 70:596-606

Costa DP, Antonelis GA, Delong RL (1991) Effects of El Niño on the foraging energetics of the California sea lion. In: Trillmich F, Ono KA (eds) Pinnipeds and El Niño: responses to environmental stress. Springer-Verlag, Berlin, p 156-165

DeLong RL, Antonelis GA, Oliver CW, Stewart BS, Lowry MC, Yochem PK (1991) Effects of the 1982-83 El Niño on several population parameters and diet of California sea lions on the California Channel Islands. In: Trillmich F, Ono KA (eds) Pinnipeds and El Niño: responses to environmental stress. Springer-Verlag, Berlin, p 166-172

Dittrich L (1987) Observations on keeping the Pacific walrus, Odobenus rosmarus divergens, at the Hanover Zoo. Int Zoo Yearb 26:163-170

> Donohue MJ, Costa DP, Goebel ME, Antonelis GA, Baker JD (2002) Milk intake and energy expenditure of freeranging northern fur seal, Callorhinus ursinus, pups. Physiol Biochem Zool 75:3-18 
Douglas DC (2010) Arctic sea ice decline: projected changes in timing and extent of sea ice in the Bering and Chukchi Seas. US Geological Survey Open-File Report 2010-1176. USGS Alaska Science Center, Anchorage, AK

Fay FH (1982) Ecology and biology of the Pacific walrus, Odobenus rosmarus divergens Illiger. N Am Fauna 74: $1-279$

Fay FH (1985) Odobenus rosmarus. Mamm Species 238:1-7

Fay FH, Burns JJ (1988) Maximal feeding depth of walruses. Arctic 41:239-240

Fay FH, Lowry LF (1981) Seasonal use and feeding habits of walruses in the proposed Bristol Bay clam fishery area. Council Document 18. North Pacific Fishery Management Council, Anchorage, AK

Fay FH, Ray GC (1968) Influence of climate on the distribution of walruses, Odobenus rosmarus (Linnaeus). I. Evidence from thermoregulatory behavior. Zoologica, NY 53:1-14

Fay FH, Stoker SW (1982a) Analysis of reproductive organs and stomach contents from walruses taken in the Alaskan native harvest, spring 1980. Final report, contract 14-16-007-81-5216. US Fish and Wildlife Service, Anchorage, AK

Fay FH, Stoker SW (1982b) Reproductive success and feeding habits of walruses taken in the 1982 spring harvest, with comparisons from previous years. Final report. Eskimo Walrus Commission, Nome, AK

Fay FH, Feder HM, Stoker SW (1977) An estimation of the impact of the Pacific walrus population on its food resources in the Bering Sea. Final report. US Marine Mammal Commission, PB-272-505. National Technical Information Service, Springfield, VA

Fisher KI, Stewart REA, Kastelein RA, Campbell LD (1992) Apparent digestive efficiency in walrus (Odobenus rosmarus) fed herring (Clupea harengus) and clams (Spisula sp.). Can J Zool 70:30-36

Fulton TL, Strobeck C (2010) Multiple fossil calibrations, nuclear loci and mitochondrial genomes provide new insight into biogeography and divergence timing for true seals (Phocidae, Pinnipedia). J Biogeogr 37:814-829

Gehnrich PH (1984) Nutritional and behavioral aspects of reproduction in walruses. MS thesis, University of Alaska, Fairbanks, AK

Gjertz I, Griffiths D, Krafft BA, Lydersen C, Wiig Ø (2001) Diving and haul-out patterns of walruses Odobenus rosmarus on Svalbard. Polar Biol 24:314-319

> Hammill MO, Lydersen C, Kovacs KM, Sjare B (1997) Estimated fish consumption by hooded seals (Cystophora cristata), in the Gulf of St. Lawrence. J Northwest Atl Fish Sci 22:249-257

Hammond K, Diamond J (1992) An experimental test for a ceiling on sustained metabolic rate in lactating mice. Physiol Zool 65:952-977

Jay CV, Fischbach AS (2008) Pacific walrus response to Arctic sea ice losses. Fact Sheet 2008-3041. US Geological Survey, http://pubs.usgs.gov/fs/2008/3041

> Jay CV, Farley SD, Garner GW (2001) Summer diving behavior of male walruses in Bristol Bay, Alaska. Mar Mamm Sci 17:617-631

> Jay CV, Marcot BG, Douglas DC (2011) Projected status of the Pacific walrus (Odobenus rosmarus divergens) in the twenty-first century. Polar Biol 34:1065-1084

Kastelein RA, Schooneman NM, Wiepkema PR (2000) Food consumption and body weight of captive Pacific walrus
(Odobenus rosmarus divergens). Aquat Mamm 26: 175-190

Kastelein RA, Klasen WJC, Postma J, Boer H, Wiepkema PR (2003) Food consumption, growth and food passage times in Pacific walrus pups at Harderwijk Marine Mammal ark Obenus rosmarus divergens. Int Zoo Yearb 38: 192-203

Kavry VI, Boltunov AN, Nikiforov VV (2008) New coastal haul-outs of walrus (Odobenus rosmarus) - response to the climate changes. In: Collect Sci Pap Mar Mammals of the Holarctic V conference, Odessa, Ukraine, 14-18 Oct 2008, p 248-251

Kleiber M (1975) The fire of life: an introduction to animal energetics. R.E. Krieger Publ. Co., Huntington, NY

> Kovacs KM, Lavigne DM (1992) Maternal investment in otariid seals and walruses. Can J Zool 70:1953-1964

Lavigne DM, Barchard W, Innes S, Øristland NA (1982) Pinniped bioenergetics. In: FAO Advisory Committee on Marine Resources Research. Working Party on Marine Mammals. FAO Fish Ser No 5. Mammals in the seas, Vol 4. Small cetaceans, Seals, Sirenians. p 191-235

Lydersen C, Aars J, Kovac KM (2008) Estimating the number of walruses in Svalbard from aerial surveys and behavioural data from satellite telemetry. Arctic 61:119-128

McDonald BI, Goebel ME, Crocker DE, Costa DP (2012) Biological and environmental drivers of energy allocation in a dependent mammal, the Antarctic fur seal pup. Physiol Biochem Zool 85:134-147

Meier WN, Stroeve J, Fetterer F (2007) Whither Arctic sea ice? A clear signal of decline regionally, seasonally and extending beyond the satellite record. Ann Glaciol 46: 428-434

> Mohn R, Bowen WD (1996) Grey seal predation on the eastern Scotian Shelf: modeling the impact on Atlantic cod. Can J Fish Aquat Sci 53:2722-2738

Noren DP (2002) Thermoregulation of weaned northern elephant seal (Mirounga angustirostris) pups in air and water. Physiol Biochem Zool 75:513-523

Noren DP (2011) Estimated field metabolic rates and prey requirements of resident killer whales. Mar Mamm Sci 27:60-77

Noren SR, Iverson SJ, Boness DJ (2005) Development of the blood and muscle oxygen stores in grey seals (Halichoerus grypus): implications for juvenile diving capacity and the necessity of a terrestrial postweaning fast. Physiol Biochem Zool 78:482-490

Oftedal OT, Iverson SJ (1987) Hydrogen isotope methodology for measurement of milk intake and energetics of growth in suckling young. In: Huntley AC, Costa DP, Worthy GAJ, Castellini MA (eds) Approaches to marine mammal energetics. Society for Marine Mammalogy Special Publication No. 1. Allen Press, Lawrence, KS, p 67-96

Olesiuk PF (1993) Annual prey consumption by harbor seals (Phoca vitulina) in the Strait of Georgia, British Columbia. Fish Bull 91:491-515

> Øristland NA, Markussen NH (1990) Outline of a physiologically based model for population dynamics. Ecol Model 52:267-288

Overland JE, Wang M (2007) Future regional Arctic sea ice declines. Geophys Res Lett 34:L17705, doi:10.1029/2007 GL030808

Ovsyanikov NG, Menyushina IE, Bezrukov AV (2008) Unusual Pacific walrus mortality at Wrangel Island in 2007. In: Collect Sci Pap Mar Mammals of the Holarctic V conference, Odessa, Ukraine, 14-18 Oct 2008, p 413-416 
Rosen DAS (2009) Steller sea lions, Eumetopias jubatus, and nutritional stress: evidence from captive studies. Mammal Rev 39:284-306

Rosen DAS, Trites AW (2000) Digestive efficiency and drymatter digestibility in Steller sea lions fed herring, pollock, squid, and salmon. Can J Zool 78:234-239

Ryg M, Øristland NA (1991) Estimates of energy expenditure and energy consumption of ringed seals (Pusa hispida) throughout the year. In: Sakshaug E, Hopkins CCE, Øristland NA (eds) Proc Pro Mare Symp Pol Mar Ecol, Trondheim, 12-16 May 1990. Polar Res 10:595-601

Schaller GB (1972) The Serengeti lion: a study of predator prey relations. University of Chicago Press, Chicago, IL

Schröder C, Bleidorn C, Hartmann S, Tiedemann R (2009) Occurrence of can-SINEs and intron sequence evolution supports robust phylogeny of pinniped carnivores and their terrestrial relatives. Gene 448:221-226

Sheffield G, Grebmeier JM (2009) Pacific walrus (Odobenus rosmarus divergens): differential prey digestion and diet. Mar Mamm Sci 25:761-777

Sheffield G, Fay FH, Feder H, Kelly BP (2001) Laboratory digestion of prey and interpretation of walrus stomach contents. Mar Mamm Sci 17:310-330

Stenson GB, Hammill MO, Lawson JW (1997) Predation by harp seals in Atlantic Canada: preliminary consumption estimates for Arctic cod, capelin, and Atlantic cod. J Northwest Atl Fish Sci 22:137-154

Trites AW, Bigg MA (1996) Physical growth of northern fur seals (Callorhinus ursinus): seasonal fluctuations and migratory influences. J Zool 238:459-482

Udevitz MS, Jay CV, Fischbach AS, Garlich-Miller JL (2009) Modeling haul-out behavior of walruses in Bering Sea ice. Can J Zool 87:1111-1128

Editorial responsibility: Peter Corkeron, Woods Hole, Massachusetts, USA
Wacasey JW, Atkinson EG (1987) Energy values of marine benthic invertebrates from the Canadian Arctic. Mar Ecol Prog Ser 39:243-250

Williams TM, Haun J, Davies RW, Fuiman L, Kohin S (2001) A killer appetite: metabolic consequences of carnivory in marine mammals. G.L. Kooyman Symposium. Comp Biochem Physiol A Comp Physiol 129:785-796

Williams TM, Rutishauser M, Long B, Fink T, Gafney J, Mostman-Liwanag H, Casper D (2007) Seasonal variability in otariid energetics: implications for the effects of predators on localized prey resources. Physiol Biochem Zool 80:433-443

Winship AJ, Trites AW (2003) Prey consumption of Steller sea lions (Eumetopias jubatus) off Alaska: How much prey do they require? Fish Bull 101:147-167

Winship AJ, Trites AW, Calkins DG (2001) Growth in body size of the Steller sea lion (Eumetopias jubatus). J Mammal 82:500-519

Winship AJ, Trites AW, Rosen DAS (2002) A bioenergetic model for estimating the food requirements of Steller sea lions Eumetopias jubatus in Alaska, USA. Mar Ecol Prog Ser 229:291-312

Winship AJ, Hunter AMJ, Rosen DAS, Trites AW (2006) Food consumption by sea lions: existing data and techniques. In: Trites AW, Atkinson SK, DeMaster DP, Fritz LW, Gelatt TS, Rea LD, Wynne KM (eds) Sea lions of the world. AK-SG-06-01. Alaska Sea Grant College Program, University of Alaska, Fairbanks, AK, p 177-191

Worthy GAJ (1987) Metabolism and growth of young harp and grey seals. Can J Zool 65:1377-1382

Worthy GAJ, Morris PA, Costa DP, Le Boeuf BJ (1992) Moult energetics of the northern elephant seal (Mirounga angustirostris). J Zool 227:257-265

Submitted: October 4, 2011; Accepted: March 5, 2012 Proofs received from author(s): July 11, 2012 